\title{
The Attitudes of Secondary School Students Toward School And Reading: A Comparison In Terms of Mother Tongue, Gender And Class Level
}

\author{
Mustafa Yıldız ${ }^{1 *}$, Yusuf Kızıltaş² \\ ${ }^{1}$ Faculty of Education, University Gazi in Ankara,Turkey \\ ${ }^{2}$ Polatoglu Primary School, Ministry of National Education, Van,Turkey
}

Corresponding author: Yusuf Kızıltaş, E-mail:ysfkiziltas@gmail.com

\section{ARTICLE INFO}

Article history

Received: November 07, 2017

Accepted: January 29, 2018

Published: January 31, 2018

Volume: 6 Issue: 1

Conflicts of interest: None

Funding: None

\begin{abstract}
It is important to determine whether the school attitude of secondary school students has an influence on the reading attitude. For this purpose, such a study was conducted at secondary school level. In addition, the extent to which such variables as mother tongue are determinative in this context has been examined.The objective of this study is to examine the relationship between the attitudes of $5^{\text {th }}, 6^{\text {th }}, 7^{\text {th }}$ and $8^{\text {th }}$ grade secondary school students toward the school and reading. In addition, the study also examines whether the attitude towards reading and school differs according to gender, class, and mother tongue variables. A total of 513 students ( 235 females, 278 males) attending secondary school in the province of Van in Turkeyparticipated in the research. In the study, Attitude Scale toward Reading developed by Alic1 (2013) is used in order to measure the attitudes of the students towards the school. Additionally, Reading Attitude Scale for Elementary Second Grade Students developed by Özbay and Uyar (2009) isused to measure the students' attitudes towards reading. According to the results, there is a moderate significant relation between students' attitudes toward the school and attitudes toward reading. According to the findings obtained from the study,it is seen that the attitudes of female students toward the school are more positive than those of male students. It is concluded that the attitudes of $5^{\text {th }}$ grade students toward the school are more positive than those of the other students. Furthermore, students whose mother tongue is Turkish have more positive reading attitudes than the students whose mother tongue is Kurdish or one of other languages (Arabic, Persian, and so on).
\end{abstract}

Key words: Attitude Toward School, Reading Attitude, Mother Tongue

\section{INTRODUCTION}

Attitudes have a very important position in our daily lives. From this aspect, attitudes help individuals to interpret their environment and guide their behaviour in the social life (Erwin, 2001). Having also an important influence on the decisions, attitudes have a strong effect on what one will do, what kind of profession one will perform, which school onewill go to, where one will live, and whether one will accept new ideas(Schafer and Tait, 1986).

Attitudes are defined by words such as emotional content, important beliefs, reactions, prejudices, evaluations and state of readiness (Çelik, 2011). Factors such as physiological factors, personality, and process of socialization, group membership and group norm contribute to the formation of attitudes as well (İnceoğlu, 2000). Within the framework of these definitions; it is possible to state that the attitude generally includes a tendency, stance, reaction.

Attitudes are influenced by personal opinions, life experiences, and they are shaped by means of education and acquire a different dimension (Hacieminoglu, 2015, p.36). In this scope; it is important to stress that there is an opportunity for students to gain important attitudes in their social and school lives. In this framework, Ataunal (2003) states that; in schools; the communication that the teacher has established with the students through positive or negative attitudes has an important influence on shaping the lives of the students. Teachers' behaviours can be imitated by the students as well as being directly accepted. This points out the importance of schools thus the teachers' responsibilities in terms of the attitudes (Uluğ, Özden, Eryılmaz, 2011, p. 739).

Schools are important institutions for the academic, psychological and social developments of the students (Sar1 and Cenkseven, 2008). The teachers and others in the school environment have an influential position for the attitudes along with the school age (Özbay and Uyar, 2008, p. 633). This situation is important for indicating the importance of schools in terms of attitude. Similarly, Alic1 (2013) also expresses that considering the individuals spend a significant part of their lives in school environment, the effects of their emotions and thoughts towards the school on the personality traits and achievements could be understood more easily. 
Studies have shown that the classrooms where the students are educated, students' socio-economic levels, ethnicities and mother tongues are influential in the formation of their attitudes as well as the schools and teachers (Hoang, 2008; Kazazoğlu, 2013; Logan, Johnston, 2009; Stagner, 2014; Wilkinson, PialDas, 2011). In this context Savignon (1976) emphasizes that the attitude has a vital importance on students' acquiring a second language. Kazazoğlu (2013) draws attention to the relationship between mother tongue (second language) and the attitude and expresses that developing a positive attitude towards the mother tongue affects the individual's entire cognition, emotion and behaviour development as well. The mother tongue, which is the first language that is naturally acquired by the person from mother, family and social environment is one of the key variables contributing to the learning and attitude development process (Kavcar, 1998;Oruç, 2016; Turkish Dictionary, 2005).

It is known that schools and school-related variables are intertwined with attitudes. It should be noted that the learning attitudes of the students who develop a positive attitude toward the school will develop as well. In particular, the attitudes towards lessons and reading are of special importance in this regard. According to Bastuğ and Keskin (2013), acquiring and investigating the reading attitudes, identifying, improving and examining the problems related to the reading process are important in terms of gaining reading interest and habit. Reading attitude is a complex and theoretical structure and is defined in various forms. Alexander and Filler (1976, as cited in DoğanandÇermik,2016) define the reading attitude as a system of feelings about reading that causes students to approach or avoid the situation of reading, whereas Smith (1990)refers to reading attitude as a mental state accompanying the feelings and emotions that accelerate the reading or cause to reduce the reading activity.

There is a dynamic relationship between reading and school attitudes, socio-cultural characteristics of students and teacher attitudes. The places where students acquire the reading attitude are, without any doubt, mainly the school environments. This has an important inflence on students' gaining attitudes towards the school. Studies conducted in this subject have tried to examine the effects of some variables on school and reading attitudes. For instance, Ünal (2006) emphasizes that the teachers' behaviours displayed and their attitudes towards students during the studies related to reading instruction are influential in developing a positive attitude towards reading by the students. In the studies carried out in order to determine the primary school students' attitudes towards reading, it is seen that the gender variable is also determinant on the reading attitudes (Balc1, 2009; Bağc1, 2010; Başaran and Ateş, 2010; Sallabaş, 2008; Uyar and Büyükikiz, 2012). Based on the results obtained from the study, it can be stated that female students have more positive attitudes towards reading compared to male students.

In the studies conducted on the $10^{\text {th }}$ grade students by Karadaş and Adigüzel (2013) and on the $9^{\text {th }}$ and $10^{\text {th }}$ grade students by Hoang (2008), it was concluded that female students developed more positive attitude towards school compared to male students whereas, it was also concluded that socio-economic level was not determinant in the attitudes of students towards the school. Similarly, Alıc1 (2013), in a study conducted on the $11^{\text {th }}$ and $12^{\text {th }}$ grade students; also points out that class level is an important variable by reaching the conclusion that the attitude towards school decreases with the increase of school level.

When the literature is examined, it is noteworthy that class level and gender concepts are important on reading and school attitudes. Apart from these factors, it may be useful to examine other factors that are considered to have an effect on students' reading and school attitudes as well. It can be said that the reading attitude, interest and habit are intertwined concepts. On the other hand, loyalty to the school, attitudes towards the school and bearing positive emotions about the school also have an important effect on the subjects such as feeling positive associations about education, continuing to school, participating in extracurricular social activities, spending extra time for school-work, reading, being able to express own opinions to the class (Mengi, 2011). In this framework, it can be said that attitudes towards reading and school are involved in an interaction.

It is observed that there is veryfew study in the literature covering both attitudes towards school and reading. In this study, the attitude towards school and the attitude of reading are emphasized and the relationship between the two subjects is discussed. The purpose of this study is to examine the relationship between secondary school students' attitudes towards school and reading and their attitudes towards school and reading in terms of various variables. For this purpose, the answers are sought for the following questions:

1. Do the attitudes of secondary school students towards school and reading differ significantly depending on the gender?

2. Do the attitudes of secondary school students towards school and reading differ significantly depending on the class level?

3. Do the attitudes of secondary school students towards school and reading differ significantly depending on their mother tongue?

4. Is there a significant relationship between the attitude towards the school and the attitude towards reading?

\section{METHOD}

\section{Study Design}

This study used a quantitative approach explore the views of students. The research is a descriptive study in the survey model. It is attempted to describe the existing situation and depending on this, the level to which the variables are related to each other is examined. According to Kaptan (1995, p. 59), this method attempts to describe "what" the events, objects, entities, institutions, groups and various areasare.

\section{Sample}

The working group of study consisted of 513 students who were selected by stratified sampling method among 
secondary schools affiliated to District Directorate of National Education of Tuşba in Van-Merkez and received training at $5^{\text {th }}, 6^{\text {th }}, 7^{\text {th }}$ and $8^{\text {th }}$ grades in 3 secondary schools with different socioeconomic levels. The distribution of the working group by class and gender is given in Table 1.

According to Table 1, it is seen that the highest number of students belongs to the $5^{\text {th }}$ Grades with 144 students whereas $6^{\text {th }}$ Grades have the least number of students with 109 persons.

\section{Instruments}

In this study, "Personal Information Form", "Attitude Scale Toward the School (OTÖ)" and "Reading Attitude Scale for Primary School Secondary Stage Students" were used as data collection tools. For the implementation of the scales in secondary schools attached to the Ministry of National Education, official permissions were obtained from the relevant institution. Then the following measuring instruments were applied by these researchers to these schools.

\section{Personal Information Form}

A personal information form was prepared by the researcher in order to measure the independent variables of the study. This form consists of questions that determine the gender, class and mother tongue of the students.

\section{Attitude Scale toward the School (OTÖ)}

Attitude Scale Toward the School, developed by Alıc (2013) consists of 25 items. Each item included in the scale is named as; ' Strongly disagree ', ' Disagree ', 'Neutral', 'Agree ' and 'Completely Agree' and rated with the help of a 5-point Likert-type grading scale. In positive statements the answers are scored from 1 to 5 starting with 'Strongly Disagree'; on the other hand the negative statements are scored by reverse coding.

As a result of the analyzes conducted within the framework of this study, the Cronbach alpha coefficient calculated for the Attitude Scale Toward the School are found to be 0.84 . The alpha values obtained from the subscales of the Attitude Scale Toward the School are found; 0.61 as an Obstacle to Personal Development for the School, 0.72 as a Supporter of Personal Development for the School, and 0.75 as a Longed Entity for the School.

Table 1. Distribution of working group by class and gender

\begin{tabular}{lcccc}
\hline Gender & $\mathbf{5}^{\text {th }}$ grade & $\mathbf{6}^{\text {th }}$ grade & $\mathbf{7}^{\text {th }}$ grade & $\mathbf{8}^{\text {th }}$ grade \\
\hline Female & 59 & 53 & 66 & 57 \\
Male & 85 & 56 & 76 & 61 \\
Total & 144 & 109 & 142 & 118 \\
\hline
\end{tabular}

It is seen that the highest number of students belongs to the $5^{\text {th }}$ grades with 144 students whereas $6^{\text {th }}$ grades have the least number of students with 109 persons

\section{Reading Attitude Scale for Primary School Secondary Stage Students}

It was developed by Özbay and Uyar (2009) in order to determine the attitudes of scondary school students towards reading. The scale is rated as a five-point Likert scale including; fully agree (5), agree (4), partially agree (3), disagree (2) and never agree (1) and it is scored between 1 and 5. The lowest score that can be received from the scale is 25 while the highest score is 125 . A total of 25 items are included in the scale, 21 of which are positive and 4 are negative, and these items are filled by the student in person. The Cronbach alpha coefficient calculated for the entire scale is found to be 0.92 . In addition, the alpha values obtained from the sub-scale; 0.85 for Free Reading sub-scale, 0.82 for Book Reading sub-scale, 0.86 for General Reading sub-scale and 0.60 for Academic Reading sub-scale. Academic reading is weak; our schools do not offer enough reading opportunities in this maneuver.

\section{Data Analysis}

SPSS(Version 22.0)was used to runindependent samples t-test in order to determine whether there is a significant difference between the two groups.One-way analysis of variance (ANOVA) was used to compare the groups more than two. In addition,Pearson product-moment correlation coefficient was performedto test the relationship between Reading Attitude and School Attitude. In all analyzes.05 significance level was taken as a criterion. The averages of attitude scores for the school and reading were considered as dependent and other variables (gender, class level, mother tongue) were considered as independent variables.

\section{FINDINGS}

The findings obtained as a result of this study aimed at determining the relationship between attitudes toward school and attitudes toward reading among the $5^{\text {th }}, 6^{\text {th }}, 7^{\text {th }}$ and $8^{\text {th }}$ grade secondary school students in reference to three categories. The descriptive statistics results of the students> attitudes toward school and reading are given in Table 2.

As can be understood from Table 2, it is seen that the reading attitude scores of the secondary school students $(M=97.5, S d=19.6)$ are quite high. It is observed that the sub-scaleof School as a Supporter of Personal Development in Reading Attitude Scale has the highest maximum average. It is seen that the attitude scores for the school $(M=75.5, S d=$ 12.6) are also high. It is seen that the maximum value of the Readingsub-scalein Attitude Scale toward the School is higher than the other sub-scaleof the scale.

\section{Findings on the School Attitude}

The values on the arithmetical mean, standard deviation and independent t-test of students' scores in the attitudes toward the school based on their genders are given in Table 3 .

When we look at the Table 3, it is observed that the gender poses a significant difference in the sum of the scale of the students' attitudes toward the school $\left(\mathrm{t}_{(511)}=5.634\right.$; 
Table 2. The arithmetic mean of the students' attitude scores for the school and reading $(n=513)$

\begin{tabular}{lcccc}
\hline Attitude & Minimum & Maximum & Mean & Standard deviation \\
\hline Obstacle & 9 & 38 & 30.9 & 5.3 \\
Support & 11 & 40 & 30.5 & 5.6. \\
Longing & 4 & 20 & 14.0 & 4.3 \\
School attitude total & 25 & 96 & 75.5 & 12.6 \\
Free reading & 7 & 35 & 27.8 & 6.7 \\
Book reading & 8 & 40 & 27.7 & 7.5 \\
Academic reading & 6 & 30 & 15.2 & 3.8 \\
General reading & 4 & 20 & 25.6 & 5.5 \\
Reading attitude total & 27 & 125 & 97.5 & 19.6 \\
\hline
\end{tabular}

Table 3. T-test results of the attitude scores of the students according to the gender variable

\begin{tabular}{|c|c|c|c|c|c|c|c|}
\hline Attitude & Gender & $\mathbf{N}$ & $\mathbf{M}$ & Sd & df & t & $\mathbf{p}$ \\
\hline \multirow[t]{2}{*}{ Obstacle } & Female & 235 & 32.2 & 4.35 & 511 & 5.323 & $0.000^{*}$ \\
\hline & Male & 278 & 29.7 & 5.78 & & & \\
\hline \multirow[t]{2}{*}{ Support } & Female & 235 & 31.6 & 4.81 & 511 & 4.137 & $0.000 *$ \\
\hline & Male & 278 & 29.6 & 6.17 & & & \\
\hline \multirow[t]{2}{*}{ Longing } & Female & 235 & 14.9 & 4.18 & 511 & 4.262 & $0.000 *$ \\
\hline & Male & 278 & 13.3 & 5.35 & & & \\
\hline \multirow[t]{2}{*}{ School Attitude.S } & Female & 235 & 72.8 & 11.0 & 511 & 5.634 & $0.000^{*}$ \\
\hline & Male & 278 & 72.7 & 13.1 & & & \\
\hline
\end{tabular}

$* \mathrm{p}<.01$

$\mathrm{p}<.01)$. This finding could be interpreted as; the attitudes of female students toward the school $(M=72.8, S d=11.0)$ is higher than the male students' attitudes toward the $\operatorname{school}(M=72.7, S d=13.1)$. There is a significant difference in the sub-scales of School as a Barrier to Personal Development $\left(\mathrm{t}_{(511)}=5.323 ; \mathrm{p}<0.01\right)$. School as a Supporter of Personal Development $\left(\mathrm{t}_{(511)}=4.137 ; \mathrm{p}<0.01\right)$. School as a Longed Entity $\left(\mathrm{t}_{(511)}=4.262 ; \mathrm{p}<0.01\right)$ of the School attitude scale. These differences are in favour of female students in all sub-scales. In this case; it can be stated that the reading attitudes of female students are higher in all sub-scales of the scale. According to the class levels of secondary school students, the arithmetic mean of attitude scores for the school is shown in Table 4.

It seems that the average of the students' attitude scores toward the school based on the class level tends to decrease as the class level increases. One-way analysis of variance was applied on the scores obtained from the entire scale of attitude toward the school and the sub-scales of the said scale, as shown in the Table 5, in order to determine whether this decrease was statistically significant. The values regarding the ANOVA test results which indicate the attitudes of the secondary school students toward the school based on their class levels are given in Table 5.

As seen in Table 5, it seems that there is a significant difference in the attitudes of the students toward the school according to the class level variable $(\mathrm{F}=3.231 ; \mathrm{p}<0.05)$. The Tukey test was used in order to determine which group this difference originated from. It is seen that the difference found significant in the total score of students' attitude scale toward the school is originated from the $5^{\text {th }}$ and $8^{\text {th }}$ grade students. It can be argued that the $5^{\text {th }}$ grade students displays attitude towards the school at a higher level than the $8^{\text {th }}$ grade students $(M=77.7, S d=11.2)$. In other words, it could be stated that the attitude toward the school decreases as the class level increases.

It is seen that there is a significant difference according to the class level variable within the sub-scaleofSchool as a Longed Entityinthe scale of attitude toward the school $(\mathrm{F}=6.775 ; \mathrm{p}<0.01)$. As a result of the Tukey test applied to determine which group this difference originated from; it is seen that this difference is originated from 5 th $-7^{\text {th }}, 5$ th$8^{\text {th }}$ and 6 th- $8^{\text {th }}$ grade students. It is seen that $5^{\text {th }}$ grade students display attitude toward the school at a higher level than $8^{\text {th }}$ grade students; and also $6^{\text {th }}$ grade students display attitude at a higher level than $8^{\text {th }}$ grade students $(M=77.7, S d=11.2)$. In other words, it could be stated that the attitude toward the school decreases as the class level increases.

The values on the arithmetical mean, standard deviation and independent t-test of students' scores in the attitudes toward the school based on their mother tongue variable are given in Table 6. When we look at the Table 6, it is seen that mother tongue does not pose a significant difference in the attitudes of students toward the school $\left(\mathrm{t}_{(511)}=1,064 ; \mathrm{p}>\right.$.05). It is seen that mother tongue is not a significant variable in attitude the school as an obstacle $\left(\mathrm{t}_{(511)}=.338 ; \mathrm{p}>.05\right)$ or as a longed entity $\left(\mathrm{t}_{(511)}=\right.$.$657 ; \mathrm{p}>.05)$. These findings; may be interpreted as the attitudes of the students whose mother tongue is Turkish towards the school are similar to those of the students whose mother tongue is Kurdish or other languages (Arabic, Persian and so on). 
When we look at the Table 6 , it is observed that there is no significant difference in the School as a Supporter of Personal Development $\left(\mathrm{t}_{(511)}=4137 ; \mathrm{p}<.05\right)$ sub-scaleof the scale. According to this finding; it can be stated that in the School as a Supporter of Personal Development sub-scaleof the attitude scale toward the school in the sub-scalethe school attitude of the students whose mother tongue is Turkish is higher than the school attitudes of the students whose mother tongue is Kurdish.

\section{Findings on the Reading Attitude}

In this section, findings indicating the students' attitudes towards reading according to gender first and then according to class level and mother tongue variable are presented. The results of the arithmetic mean, standard deviation, and in-

Table 4. The arithmetic mean of the students' attitude scores toward the school according to class level

\begin{tabular}{lcccc}
\hline School attitude & $\begin{array}{c}\text { Class } \\
\text { level }\end{array}$ & $\mathbf{N}$ & Mean & $\begin{array}{c}\text { Standard } \\
\text { deviation }\end{array}$ \\
\hline Obstacle & 5 & 144 & 31.3 & 4.83 \\
& 6 & 109 & 31.3 & 5.30 \\
Support & 7 & 142 & 30.5 & 5.87 \\
& 8 & 118 & 30.4 & 5.19 \\
& 5 & 144 & 31.3 & 5.18 \\
Longing & 6 & 109 & 30.1 & 6.72 \\
& 7 & 142 & 30.5 & 5.18 \\
& 8 & 118 & 29.8 & 5.71 \\
& 5 & 144 & 15.0 & 4.03 \\
& 6 & 109 & 14.6 & 4.16 \\
& 7 & 142 & 13.5 & 4.71 \\
& 8 & 118 & 12.9 & 4.11 \\
& 5 & 144 & 77.7 & 11.2 \\
& 6 & 109 & 76.1 & 13.7 \\
& 7 & 142 & 74.6 & 13.2 \\
& 8 & 118 & 73.2 & 11.8 \\
\hline
\end{tabular}

dependent groups t-test regarding the attitude scores of students toward reading in accordance with their genders are given in Table 7.

When Table 7 is examined, it is observed that male and female studenst have a significant difference in the attitudes of students toward reading $\left(\mathrm{t}_{(511)}=6.859 ; \mathrm{p}<0.01\right)$. This finding implies that female students' attitudes toward reading are higher.

It is seen that there is a significant differencein the subscales of Free Reading $\left(\mathrm{t}_{(511)}=6.164 ; \mathrm{p}<0.05\right)$, Book Reading $\left(\mathrm{t}_{(511)}=5.537 ; \mathrm{p}<0.05\right)$, General Reading $\left(\mathrm{t}_{(511)}=4.860\right.$; $\mathrm{p}<0.05)$ and Academic Reading $\left(\mathrm{t}_{(511)}=5.816 ; \mathrm{p}<0.05\right)$ of the reading attitude scale. These differences are in favour of female students in all sub-scales. In this case; it can be stated that the students' attitudes toward reading are higher in all sub-scales of the scale. The arithmetic mean of secondary school students' attitude scores towards reading according to the class levels are presented in Table 8.

Significant differences appear in the average of students' attitude scores toward reading according to the class level. One-way analysis of variance is applied on the scores obtained from the whole scale of attitude toward reading and its sub-scales in order to determine whether this difference is statistically significant. The values on one-way analysis of variance (ANOVA) results indicating the secondary school students' attitudes toward reading according to their class levels are given in Table 9.

As seen in Table 9, it is observed that the students who study in different grades have a significant difference regarding the attitudes toward reading in the total of the scale according to the class level variable $(F=5.175 ; p<0.05)$. When the average scores of students' reading attitude scale are examined, $5^{\text {th }}$ Grade students have the highest attitudes toward reading $(M=100, S d=19.2)$.

It is seen that there is not a significant differencein the scores of General Readingsub-scaleof Reading Attitude Scale $(F=461 ; p>0.05)$. It is observed that there is a significant difference in the scores of Free Reading ( $\mathrm{F}=4.820$; $\mathrm{p}<0.05)$ Book Reading ( $\mathrm{F}=7.180 ; \mathrm{p}<0.05)$ and Academic Reading $(\mathrm{F}=6.142 ; \mathrm{p}<0.05)$ sub-scales of the Reading Atti-

Table 5. ANOVA results on the attitude scores of the students based on the class level

\begin{tabular}{|c|c|c|c|c|c|c|}
\hline Attitude & Sum of squares & df & Mean of squares & $\mathbf{F}$ & Sig & \\
\hline \multirow[t]{3}{*}{ Obstacle } & 95.100 & 3 & 31.700 & 1.121 & 0.340 & \\
\hline & 14392.8 & 509 & 28.277 & & & \\
\hline & 144877.9 & 512 & & & & \\
\hline \multirow[t]{3}{*}{ Support } & 167.925 & 3 & 55.975 & 1.742 & 0.157 & \\
\hline & 16351.5 & 509 & 32.125 & & & \\
\hline & 16519.43 & 512 & & & & \\
\hline \multirow[t]{3}{*}{ Longing } & 372.041 & 3 & 124.014 & 6.775 & $0.000 * *$ & $5-7$ \\
\hline & 9317.08 & 509 & 18.305 & & & $5-8$ \\
\hline & 96819.12 & 512 & & & & $6-8$ \\
\hline School attitude & 1520.076 & 3 & 506.692 & 3.231 & $0.022 *$ & $5-8$ \\
\hline \multirow[t]{2}{*}{ Scale } & 79810.173 & 509 & 156.698 & & & \\
\hline & 81330.250 & 512 & & & & \\
\hline
\end{tabular}

$* \mathrm{p}<0.05,{ }^{* *} \mathrm{p}<0.01$ 
Table 6. $\mathrm{t}$ - test results of the students' attitude scores toward the school according to mother tongue variable

\begin{tabular}{|c|c|c|c|c|c|c|c|}
\hline Attitude & Mother tongue & $\mathbf{N}$ & Mean & Standard deviation & df & $t$ & $\mathbf{p}$ \\
\hline \multirow[t]{2}{*}{ Obstacle } & Turkish & 359 & 30.9 & 5.36 & 511 & 0.338 & 0.735 \\
\hline & Kurdish/others & 154 & 30.7 & 5.22 & & & \\
\hline \multirow[t]{2}{*}{ Support } & Turkish & 359 & 30.9 & 5.18 & 511 & 2.560 & $0.011 *$ \\
\hline & Kurdish/others & 154 & 29.5 & 6.61 & & & \\
\hline \multirow[t]{2}{*}{ Longing } & Turkish & 359 & 13.9 & 4.21 & 511 & $0 .-657$ & 0.511 \\
\hline & Kurdish/others & 154 & 14.2 & 4.65 & & & \\
\hline School attitude & Turkish & 359 & 75.8 & 12.1 & 511 & 1.064 & 0.288 \\
\hline Scale & Kurdish/others & 154 & 74.5 & 13.6 & & & \\
\hline
\end{tabular}

Table 7. T - test results of students' attitude scores toward reading according to the gender variable

\begin{tabular}{|c|c|c|c|c|c|c|c|}
\hline Attitude & Gender & $\mathbf{N}$ & Mean & Standard deviation & df & $\mathbf{t}$ & $\mathbf{p}$ \\
\hline \multirow[t]{2}{*}{ Free reading } & Female & 235 & 29.7 & 5.42 & 511 & 6.164 & $0.000^{*}$ \\
\hline & Male & 278 & 26.1 & 7.37 & & & \\
\hline \multirow[t]{2}{*}{ Book reading } & Female & 235 & 29.6 & 6.78 & 511 & 5.537 & $0.000^{*}$ \\
\hline & Male & 278 & 26.0 & 7.77 & & & \\
\hline \multirow[t]{2}{*}{ General reading } & Female & 235 & 26.8 & 4.13 & 511 & 4.860 & $0.000^{*}$ \\
\hline & Male & 278 & 24.5 & 6.31 & & & \\
\hline \multirow[t]{2}{*}{ Academic reading } & Female & 235 & 16.3 & 3.46 & 511 & 5.816 & $0.000^{*}$ \\
\hline & Male & 235 & 14.3 & 3.98 & & & \\
\hline \multirow[t]{2}{*}{ Reading attitude S. } & Female & 235 & 102.6 & 15.7 & 511 & 6.859 & $0.000^{*}$ \\
\hline & Male & 278 & 91.1 & 21.1 & & & \\
\hline
\end{tabular}

$* \mathrm{p}<0.01$

tude Scale. Tukey test is applied in order to determine which group these differences originate from.

The difference observed withinFree Readingsub-scales of reading attitude scale,originate from the scores of $5-8^{\text {th }}$ grades and6- $8^{\text {th }}$ grades. Accordingly, reading attitudes of $5^{\text {th }}$ grade students $(M=29, S d=6.59)$ are higher than the reading attitudes of $8^{\text {th }}$ grade students $(M=26, \mathrm{Sd}=6.82)$; and also reading attitudes of $6^{\text {th }}$ grade students $(M=28.4, \mathrm{Sd}=6.68)$ are higher than the reading attitudes of $8^{\text {th }}$ grade students. Likewise, the difference observed in Readingsub-scaleoriginates from 5-8 ${ }^{\text {th }}$ grades and $6-8^{\text {th }}$ grades as in Free Readingsub-scale. Reading attitudes of $5^{\text {th }}$ grade students $(M=29.4, S d=7.30)$ are higher than the reading attitudes of $8^{\text {th }}$ grade students $(M=25.4, S d=5.01)$; and also reading attitudes of $6^{\text {th }}$ grade students $(M=28.7, S d=7.30)$ are higher than the reading attitudes of $8^{\text {th }}$ grade students.

Similarly, the difference observed in Academic Readingsub-scaleof reading attitude scale,originates from the scores of5- $8^{\text {th }}$ grades and $6-8^{\text {th }}$ grades. Reading attitudes of $5^{\text {th }}$ grade students $(M=15.7, S d=3.71)$ are higher than the reading attitudes of $8^{\text {th }}$ grade students $(M=14, S d=3.76)$; and also reading attitudes of $6^{\text {th }}$ grade students $(M=16, S d=3.84)$ are higher than the reading attitudes of $8^{\text {th }}$ grade students.

When Table 8 is examined, it is seen that the difference which is found as significant in the sum of reading attitude scale for students originates from the scores of 5 th$8^{\text {th }}$ grades and6th- $8^{\text {th }}$ grades. Accordingly reading attitudes of $5^{\text {th }}$ grade students $(M=100, S d=19.2)$ are higher than the reading attitudes of $8^{\text {th }}$ grade students $(M=91.0, S d=18.5)$. In general terms, it could be stated that $5^{\text {th }}$ grade students display a higher level of attitude toward reading. In addition to this, reading attitudes of $6^{\text {th }}$ grade students $(M=16, S d=3.84)$ are higher than the reading attitudes of $8^{\text {th }}$ grade students. The values on the arithmetic mean, standard deviation and independent t-testof students' attitude scores toward reading according to mother tongue variableare given in Table 10 .

When we examine the Table 10, there is not a significant difference in the sub-scalesof Reading $\left(\mathrm{t}_{(511)}=0.077 ; \mathrm{p}>0.05\right)$ and General Reading $\left(\mathrm{t}_{(511)}=.995 ; \mathrm{p}>0.05\right)$ of the attitude scale. This finding, in the context of the Reading Book and General Reading sub-scalesof the scale, can be interpreted that the attitudes of the students whose mother tongue is Turkish and the students whose mother tongue is Kurdish or one of other languages (Arabic, Persian and so on) are similar.

No significant difference is observed in the sub-scalesof Free Reading ( $\left.{ }_{(511)}=2.604 ; \mathrm{p}<0.05\right)$, Academic Reading $\left(\mathrm{t}_{(511)} 3.352 ; \mathrm{p}<0.05\right)$ and the scores obtained from the sum of scale $\left(\mathrm{t}_{(511)}=2061 ; \mathrm{p}<0.05\right)$ based on the mother tongue variable with regard to attitudes of students toward reading. According to this; in the context of Free Readingsub-scale of the scale, the reading attitudes of students whose mother tongue is Turkish $(M=28.3, S d=6.5)$ are higher than the reading attitudes of students whose mother tongue is Kurdish or one of other languages (Arabic, Persian and so on) $(M=26.6, S d=7.1)$. Likewise, in the context of Academic Readingsub-scale of the scale, the reading attitudes of stu- 
Table 8. The arithmetic mean of the students'attitude scores toward reading according to class level

\begin{tabular}{lcccccc}
\hline Attitude & Class level & n & Minimum & Maximum & Mean & Standard deviation \\
\hline Free reading & 5 & 144 & 7 & 35 & 29.0 & 6.59 \\
& 6 & 109 & 7 & 35 & 28.4 & 6.68 \\
Book reading & 7 & 142 & 7 & 35 & 27.5 & 6.74 \\
& 8 & 118 & 7 & 35 & 26.0 & 6.82 \\
General reading & 5 & 144 & 8 & 40 & 29.4 & 7.30 \\
& 6 & 109 & 8 & 40 & 28.7 & 7.30 \\
Academic reading & 7 & 142 & 8 & 40 & 27.0 & 7.56 \\
& 8 & 118 & 8 & 40 & 25.4 & 7.45 \\
& 5 & 144 & 6 & 30 & 25.8 & 5.96 \\
Reading attitude scale & 6 & 109 & 6 & 30 & 25.1 & 6.21 \\
& 7 & 142 & 6 & 30 & 25.9 & 4.99 \\
& 8 & 118 & 6 & 30 & 25.4 & 5.01 \\
& 5 & 144 & 4 & 20 & 15.7 & 3.71 \\
& 6 & 109 & 4 & 20 & 16.0 & 3.84 \\
& 7 & 142 & 4 & 20 & 15.0 & 3.93
\end{tabular}

$* \mathrm{p}<0.01$

Table 9. ANOVA results on the students' attitude scores toward reading according to class level

\begin{tabular}{|c|c|c|c|c|c|c|}
\hline Attitude & Sum of squares & df & Mean of squares & $\mathbf{F}$ & sig & \\
\hline \multirow[t]{3}{*}{ Free reading } & 650 & 3 & 216.958 & 4.820 & $0.003 *$ & $5-8$ \\
\hline & 22910 & 509 & 45.011 & & & $6-8$ \\
\hline & 23561 & 512 & & & & \\
\hline \multirow[t]{3}{*}{ Book reading } & 1184 & 3 & 394.719 & 7.180 & $0.000^{*}$ & $5-8$ \\
\hline & 27980 & 509 & 54.972 & & & $6-8$ \\
\hline & 29165 & 512 & & & & \\
\hline \multirow[t]{3}{*}{ General reading } & 4269 & 3 & 14.231 & 0.461 & 0.710 & \\
\hline & 15718 & 509 & 30.881 & & & \\
\hline & 81330 & 512 & & & & \\
\hline \multirow[t]{3}{*}{ Academic reading } & 268 & 3 & 89.473 & 6.142 & $0.000^{*}$ & $5-8$ \\
\hline & 7414 & 509 & 14.567 & & & $6-8$ \\
\hline & 7683 & 512 & & & & \\
\hline \multirow[t]{3}{*}{ Reading attitude scale } & 5865 & 3 & 1955.068 & 5.175 & $0.002 *$ & $5-8$ \\
\hline & 192283 & 509 & 377.067 & & & $6-8$ \\
\hline & 198148 & 512 & & & & \\
\hline
\end{tabular}

$$
* \mathrm{p}<.01
$$

dents whose mother tongue is Turkish $(M=26.1, S d=4.7)$ are higher than the reading attitudes of students whose mother tongue is Kurdish or one of other languages (Arabic, Persian and so on) ( $M=24.3, S d=6.8)$.

When we examine the scores obtained from the sum of the scale in Table 10, reading attitudes of the students whose mother tongue is Turkish $(M=97.5, S d=18.8)$ are higher than the reading attitudes of students whose mother tongue is Kurdish or one of other languages (Arabic, Persian and so on) $(M=93.5, S d=21.3)$.

\section{Findings on the Relation Between School Attitude and Reading Attitude}

Pearson correlation analysis method is used to determine the relationship between students' attitudes toward the school 
and their attitudes towards reading. If the correlation coefficient indicating the relation between the analyzed variables is between 1.00 and 0.70 as absolute value, the relation is regarded as high; and if the said correlation coefficient is between 0.70 and 0.30 it is regarded as medium and if it is between 0.30 and 0 , the relation is regarded as a low level (Büyüköztürk, 2003). Table 11 indicates the Pearson correlation analysis results that test the relationship between the attitude toward the school and the attitude toward reading within the scope of the study.

When we examine the Table 11, there is a significant relationship between the determined Reading Attitude Scale and its sub-scalesand the Attitude Scale toward Reading and its sub-scalesas a result of the correlation analysis. When the relation between the sub-scale ofFree Reading and the Scale of School Attitude is examined; there is a moderate relation in positive direction $(\mathrm{r}=0.57)$; in terms of relation between the sub-scale of Book Reading and Scale of School Attitude, there is a moderate relation in positive direction $(\mathrm{r}=0.54)$; in terms of relation between the sub-scale ofAcademic Reading and Scale of School Attitude there is a moderate relation in positive direction $(\mathrm{r}=0.66)$ and in terms of relation between the sub-scale of General Reading and Scale of School Attitude there is a moderate relation in positive direction $(\mathrm{r}=0.53)$. Similarly, there is also a moderate relation in pos- itive direction between the scores of Reading Attitude Scale and the Attitude Scale toward School $(r=0.69)$.

\section{DISCUSSION}

In this study, the relationship between school attitude and reading attitude is emphasized. As a result of the study, it is concluded that the gender variable is decisive on the attitudes of the secondary school students toward the school. To state more explicitly, female students' attitudes toward the school are higher than male students' attitudes towards the school. Some studies conducted on this subject (such as, Alıc1, 2013; Karadaş and Adıgüzel, 2013) have concluded that the attitudes of female students toward the school are higher than that of male students. Similarly Wilkinson and Das (2011), as a result of the study in which they tried to determine the effect of age, gender, class level on the learning environment and school attitude, found that female students had a higher level of school attitudes compared to male students. In a study named examining the variables that predict perceptions of primary school students toward the school environment Özdemir et al. (2010) concluded that female students had a higher level of attitude compared to male students. Conversely, in a study conducted by Hoang (2008) examining class level, age, gender and ethnicity on learning

Table 10. T-test results of students' attitude scores toward reading according to the mother tongue variable

\begin{tabular}{|c|c|c|c|c|c|c|}
\hline Attitude & Mother tongue & $\mathbf{N}$ & Mean & Standard deviation & $\mathbf{t}$ & $\mathbf{p}$ \\
\hline \multirow[t]{2}{*}{ Free reading } & Turkish & 359 & 28.3 & 6.5 & 2.604 & $0.009 *$ \\
\hline & Kurdish/others & 154 & 26.6 & 7.1 & & \\
\hline \multirow[t]{2}{*}{ Book reading } & Turkish & 359 & 27.7 & 7.5 & 0.077 & 0.938 \\
\hline & Kurdish/others & 154 & 27.6 & 7.4 & & \\
\hline \multirow[t]{2}{*}{ Academic reading } & Turkish & 359 & 26.1 & 4.7 & 3.352 & $0.001 *$ \\
\hline & Kurdish/others & 154 & 24.3 & 6.8 & & \\
\hline \multirow[t]{2}{*}{ General reading } & Turkish & 359 & 15.3 & 3.9 & 0.995 & 0.320 \\
\hline & Kurdish/others & 154 & 14.9 & 3.7 & & \\
\hline \multirow[t]{2}{*}{ Reading attitude scale } & Turkish & 359 & 97.5 & 18.8 & 2.061 & $0.040^{*}$ \\
\hline & Kurdish/others & 154 & 93.5 & 21.3 & & \\
\hline
\end{tabular}

$* \mathrm{p}<0.05$

Table 11. Correlation matrix of relations between the variables of attitude toward school and reading

\begin{tabular}{|c|c|c|c|c|c|c|c|c|c|}
\hline Variables & 1 & 2 & 3 & 4 & 5 & 6 & 7 & 8 & 9 \\
\hline Free reading & - & & & & & & & & \\
\hline Book reading & $0.71^{*}$ & - & & & & & & & \\
\hline Academic reading & $0.54^{*}$ & $0.48^{*}$ & - & & & & & & \\
\hline General reading & $0.65^{*}$ & $0.49 *$ & $0.42 *$ & - & & & & & \\
\hline Reading attitude total & $0.90^{*}$ & $0.86^{*}$ & $0.68^{*}$ & $0.78^{*}$ & - & & & & \\
\hline Obstacle* & $0.49 *$ & $0.44 *$ & $0.52 *$ & $0.49 *$ & $0.58 *$ & - & & & \\
\hline Support* & $0.45^{*}$ & $0.36^{*}$ & $0.39 *$ & $0.67^{*}$ & $0.56^{*}$ & $0.49 *$ & - & & \\
\hline Longing* & $0.44 *$ & $0.54^{*}$ & $0.40^{*}$ & $0.44 *$ & $0.57 *$ & $0.52 *$ & $0.51^{*}$ & - & \\
\hline School attitude & $0.57 *$ & $0.54 *$ & $0.53 *$ & $0.66^{*}$ & $0.69 *$ & $0.82 *$ & $0.83 *$ & $0.79 *$ & - \\
\hline Total & & & & & & & & & \\
\hline
\end{tabular}


environments and attitudes of $9^{\text {th }}$ and $10^{\text {th }}$ grade students; it was concluded that male students had a higher and more positive level of school attitude compared to female students.

A significant difference was found between the class level of the students and their school attitudes. $5^{\text {th }}$ grade students have a higher attitude toward the school. On the other hand, the attitudes of the $8^{\text {th }}$ grade students toward the school have been the lowest. This result; may also be expressed that there is a decrease in the attitudes of the secondary school students toward the school as the class level increases. Likewise, Alıc1 (2013), in a study conducted on high school students, found that $9^{\text {th }}$ grade students had the highest level of attitudes toward the school and on the other hand $12^{\text {th }}$ grade students had the lowest attitudes.Özdemir et al. (2010) found that the pressure on the students increased as the class level increased, and that the attitude toward the school and the achievement decreased. Y1ldiz (2013), in a study conducted on the reading motivations of the primary school students, indicates that primary school students' interests and curiosity toward studying decrease as they grow older. In other words, it is emphasized that both internal and external motivations decrease as the class level increases. This, undoubtedly, sheds light on the fact that the level of attitude toward reading is also affected negatively. In this context, Aric1 (2005) expresses that the fact that there are more entertaining stimuli in the technological age we live in, could be an important factor; and that there could be problems arising from family, school, and teacher as well. In this framework, Balc1 (2009) states that the reasons that affect the attitude of reading (preparing for test type examinations, excessive attention towards computer, watching television, and so on) must be investigated within the framework of various variables.

It was determined that there was no significant difference in the students' attitudes toward the school according to their mother tongue. In other words, the use of Turkish, Kurdish, or one of the other languages (Arabic, Persian, and so on) in the family does not pose a significant difference on the attitude of students toward the school. In general terms, this shows that schools in Turkey do not exclude students with different mother tongues and schools have an inclusive culture in this sense.

On the other hand, in the study conducted by Şekerci and Y1lmaz (2016), it was concluded that the mother tongue difference caused students to develop negative attitudes toward the school and teachers. In the sub-scale of School as the Supporter of Personal Development, it is seen that the mother tongue variable is effective. This result show thatstudents whose mother tongue is Turkish have more positive attitudes of toward the school than the students whose mother tongue is Kurdish and one of other languages. Alic1 (2013), in relation to the statements included in the sub-scale of School as the Supporter of Personal Development, states that the attitudes toward the school include more cognitive orientation and include items expressing the belief in the value and importance of the school in terms of academic and personal development. In this case, the students whose mother tongue is Kurdish and one of other languagesbelieve that the school does not support them to improve their academic and personal development as much as the native speakers of Turkish. The ways of reducing the negative attitudes of the students and eliminating their disadvantaged situation in this regard are not related to teaching students whose mother tongue is different, with their own languages as as stated by Gay (2014, as cited inŞekerci and Y1lmaz, 2016). It is understood that there is a need for policies to improve the Turkish proficiencies of the students who have different mother tongue, to support such students in academic terms and to develop programs and materials in order to compensate for their deficiencies. Because Freire and Macedo (1998) point out that training the students ina different langue apart from the national language will have negative consequences against the student.In the study; it is concluded that the attitudes of female students toward reading are higher than the attitudes of male students. Sallabaş (2008) also, in a study conducted on the attitudes of $8^{\text {th }}$ grade students toward reading, concluded that the attitudes of female students toward reading were higher than that of male students. In a study conducted on the $8^{\text {th }}$ grade students, Balc1 (2009) found that female students> attitudes towards reading were higher than the attitudes of male students. It would be wrong to say that the said studies are limited to $8^{\text {th }}$ grade students in primary schools. In other words, the fact that the reading attitudes of female students are higher than the reading attitudes of male students is supported by many research results. Moreover, when we look at these results, it is observed that this situation is based on the class level as well. For instance, this finding is also supported by the finding of another study conducted by Ateş and Başaran (2009) on primary school $5^{\text {th }}$ grade students. İşeri (2010) reached the conclusion that the average reading attitude scores of primary school second grade students differed in favour of the females depending on their genders. Similarly, in Bağc1>s (2010) study, the conclusion stating that attitudes of primary school second grade students toward reading differ significantly in favour of female students according to their genders, also supports the finding obtained in this study. As a result of the study which was conducted by Balcı, Uyar and Büyükikiz (2012) for examining the relationship between the reading habits, frequency of library use and reading attitudes of $6^{\text {th }}$ grade primary school students, female students> attitudes toward reading were found to be higher than reading were higher than the male students. In conclusion, it can be stated that the results obtained from this study conducted on the secondary school students and the results obtained from the literature support each other.

As a result of the study, it is seen that the reading attitudes of the $5^{\text {th }}$ grade students are the highest. This situation is respectively followed by $6^{\text {th }}, 7^{\text {th }}$ and $8^{\text {th }}$ Grades. This finding can be interpreted as there is a decrease in reading attitudes as the class level increases. In the study conducted by Baş (2012) on the $9^{\text {th }}, 10^{\text {th }}, 11^{\text {th }}$ and $12^{\text {th }}$ grades, it was concluded that the attitudes of the high school students toward reading were moderate and the reading attitudes of the $9^{\text {th }}$ grade students were higher than the reading levels of the students at the other class levels. Similarly, in other studies conducted on the reading attitudes of the $6^{\text {th }}, 7^{\text {th }}$, and $8^{\text {th }}$ grades, it was concluded that the highest reading level was displayed by $6^{\text {th }}$ grades in other words the reading attitudes decreased as 
the class level increased (Ateş, 2009; İșeri, 2010; McKenna et al., 1995; Stange and Carter, 1995).

It has been found that the mother tongue of secondary school students has a significant influence on their reading attitudes. According to this result, it can be said that the students whose mother tongue is Turkish have higher attitudes toward reading than the students whose mother tongue is Kurdish or one of other languages (Arabic, Persian and so on). When all the items of scale are examined; it can be stated that reading activity is not valuable and important in the lives of students whose mother tongue is Kurdish or one of other languages. The lack of reading habits may have been influential in the development of this attitude by the students. When the relevant items in theAcademic Readingsub-scale of the scale are examined, it is understood that the items involve statements about the reading activities of students from their textbooks. Academic reading refers to using the reading activity for the purposes of learning and acquisition of knowledge. It is shown that the students whose mother tongue is Kurdish or one of other languages have some deficiencies in terms of using the reading activity for learning purposes. In addition, Ulusoy (2009) emphasizes that textbooks are difficult for students to read, and that the books in question should be made suitable so that students could read. When the items in theFree Readingsub-scale of the scale are examined, it is seen that the items involve the statements of students about reading books during their leisure time, alone times and when they are outside the school. This result can be interpreted as the fact that the school textbooks and reading activities fail in terms of minimizing the disadvantages arising from the mother tongue differences and this leads to a negative attitude toward reading by the students whose mother tongue is Kurdish and one of other languages.

It seems that a moderate relationship has appeared between the attitudes of the secondary school students toward the school and their attitudes toward reading. According to this, it can be stated that the attitudes of the students toward the school are positively affecting the reading attitudes of the students. It can be said that the activities which keep the students' interests alive at school, the content which meets their expectations and the factors which make students become part of the school will create a positive attitude within the context of school. It is possible that this attitude will especially contribute to situations such as reading then academic success and continuity.

\section{CONCLUSION}

It is undoubtedly necessary to emphasize that there are also some limitations of this study which is conducted with the aim of determining secondary school students' reading and school attitudes. We can specify that we have limited the sample of the study at the secondary school level. It is suggested that the level of elementary school is also an important factor, and this field can be suggested to the researchers who will conduct studies in this regard. Although the lack of teacher opinions is a limitation for this study, it can be regarded as extremely appropriate and proper recommendation for future researchers.
It is necessary to express that other reading skills such as fluent reading and reading comprehension could be taken into consideration by future researchers while examining the levels of some variables by which the reading attitudes influenced. As it has been concluded that the mother tongue is determinant on the attitudes of school and reading in particular, it is also an important recommendation to investigate whether this variable will be effective on the academic success. As is the case in many research studies, it has been concluded that female students have higher levels of reading attitudes compared male students in this study and we can state that the cause of this situation is open for investigation.

With regard to students whose mother tongue is different, it is a non-negligible recommendation for Ministry of National Education to ensure that the opinions of bilingual teachers or training managers that is experienced teachers having comprehensive knowledge about the languages other than Turkish or that the teachers would be trained in terms of different mother tongues. It is also necessary to emphasize that the disadvantages experienced by students with different mother tongues when they start elementary school can be minimized by means of language-centred activities and programs by making pre-school education compulsory. Also, it is understood that the policies are required to be developed for students whose mother tongue is different from Turkish so that their Turkish competencies are improved, they are supported in academic terms and the programs and materials are developed in order to compensate for their shortcomings.

\section{REFERENCES}

Adıgüzel, D. K. (2013). Ortaöğretim öğrencilerinin okula yönelik tutumlarının devamsızlık ve okul başarıları üzerindeki etkisi. YYÜ Eğitim Fakültesi Dergisi, 10 (168), 49-66.

Alıcı, D. (2013). Okula yönelik tutum ölçeğinin geliştirilmesi: güvenirlik ve geçerlik çalışması. Eğitim ve Bilim, 38 (168), 318-331.

Arıc1, A. F. (2005). İlköğretim ikinci kademe öğrencilerinin okuma durumları: beceri-ilgi-alışkanlık-eğilim(Yayımlanmamış doktora tezi). Erzurum: Atatürk Üniversitesi Sosyal Bilimler Enstitüsü.

Ataunal, A. (2003). Niçin ve nasıl bir ögrretmen?(Why and what kind of teacher?). Ankara: Milli Eğitim Vakfi Yayınları.

Bağc1, H. (2010). İlköğretim II. Kademe öğrencilerinin okumaya yönelik tutumlarının değerlendirilmesi. II. Uluslararası Dünya Dili Türkçe Sempozyumu. Lefkoşa, Kıbris: Uluslararası Kıbris Üniversitesi.

Balc1, A. (2009). İlköğretim 8. sınıf öğrencilerinin okumaya yönelik tutumları ve okuduğunu anlama düzeyleri. Journal of New World Sciens Academy Education Sciens, 4 (4), 1308-1330.

Balc1, A. U. (2012). İlköğretim 6. sınıf öğrencilerinin okuma alışkanlıkları, kütüphane kullanma sıklıkları ve okumaya yönelik tutumlarının incelenmesi. Turkısh Studies, 7 (4), 965-985.

Başaran, M. A. (2009). İlköğretim beşinci sınıf öğrencilerinin okumaya ilişkin tutumlarının İncelenmesi. Gazi 
Eğitim Fakültesi Dergisi, 29 (1), 73-92.

Baştuğ, M. K. (2013). Ergenlik dönemi okuma tutumu ölçeği'nin

Türkçeye uyarlanması. Turkish Studies, 8 (4), 295-311.

Cialdini, R., Petty, R., \& Cacioppo, J. (1981). Attitude and

attitude change. 8 1, 2017 tarihinde http://www.psy. ohio-state.edu/petty/PDF\%20Files/1981-AnnRev-Cialdini,Petty,Cacioppo.pdf adresinden alınd 1

Das, K. P. and Wilkinsonand, M. D. (2011). The Effects of gender, class level and ethnicity on attitude and learning environment in college algebra course. The Journal of Mathematical Sciences and Mathematics Education, 6 (2), 44-55.

Çelik, S. (2011). Öğretmen tutumları ile ilköğretim 5. sınıf ögrencilerinin benlik saygısı düzeyleri arasındaki ilişki. Yayımlanmamış yüksek lisans tezi. Konya: Selçuk Üniversitesi Sosyal Bilimler Enstitüsü.

Erwin, P. (2001). Attitudes and Persuasion. London: Psychology Press.

Eser, H. (2012). Dinin siyasal davranışlar üzerindeki etkisi: Antalya örnek olay araştırması. Gazi Üniversitesi Iktisadi ve İdari Bilimler Fakültesi Dergisi, 14 (3), 97-136.

Freire, P. M. (1998). Okuryazarlı: Sözcükleri ve Dünyayı Okuma (S, Ayhan, Çev.). Ankara: İmge Yayıncılı.

Güngör, A., \& Un Açıkgöz, K. (2006). İşbirlikli öğrenme yönteminin okuduğunu anlama stratejilerinin kullanımı ve okumaya yönelik tutum üzerindeki etkileri. Kuram ve Uygulamada Eğitim Yönetimi, 48, 481-502.

Hacieminoğlu, E. (2015). Elementary school students'attitude toward science and related variables. International Journal of Environmental \& Science Education, 11 (2), 35-52.

Hoang, T. (2008). The Effects of grade level, gender, and ethnicity on attitudeand learning environment in mathematics in high school. (I. E. Education, Dü.) 7, 1, 2016 tarihinde http://www.jejme.com: http://www.jejme. com/12008/d3.pdf adresinden alınd 1

İnceoğlu, M. (2004). Tutum, algl, iletişim. Ankara: Elips Kitap.

İşeri, K. (2010). İlköğretim ikinci kademe öğrencilerinin okuma tutumlarının incelenmesi. Uluslararast Insan Bilimleri Degisi, 7 (2), 468-487.

Kaptan, S. (1995). Bilimsel araştırma ve istatistik teknikleri. Ankara: Rehber Yayınevi.

Kavcar, C. (1998). Türkçe eğitimi ve sorunlar. Dil Dergisi (65), 5-18.

Kazazoğlu, S. (2013). Türkçe ve ingilizce derslerine yönelik tutumun akademik başarıya etkisi. Eğitim ve Bilim, 38 (170), 294-307.

Logan, S. J. (2009). Gender differences in reading ability and attitudes: Examining where these differenceslie. Journal Of Research in Reading, 32 (2), 199-214.

Mc Kenna, M., \& C., K. D. (1995). Children's attitudes toward reading: A national survey. Reading Research Quartely, 30, 934-956.

Mengi, S. (2011). Ortaöğretim 10. ve 11. Sinif ögrencilerinin sosyal destek ve öz-yeterlik düzeylerinin okula bağlılıkları ile ilişkisi (Yayımlanmamış yüksek lisans tezi). Sakarya: Sakarya Üniversitesi Sosyal Bilimler Enstitüsü.

Oruç, Ş. (2016). Türkçede ana dil ve ana dili. Littera Turca Journal of Turkish Language andLiterature, 2 (1), 311-322.
Özbay, M., \& Uyar, Y. (2009). lköğretim ikinci kademe

öğrencileri için okumaya yönelik tutum ölçeğinin geliștirilmesi: Geçerlilik ve güvenirlik çalışması. Journal of New World Sciences Academy Education Sciences, 4 (2), 632-651.

Özdemir, S., Sezgin, F., Şirin, H., Karip, E., \& Erkan, S. (2010). ilköğretim okulu öğrencilerinin okul iklimine ilişkin algılarını yordayan değişkenlerin incelenmesi. Hacettepe Üniversitesi Eğitim Fakültesi Dergisi (H.U. Journal of Education), 38, 213-224.

Sallabaş, M. (2008). İlköğretim 8. sınıf öğrencilerinin okumaya yönelik tutumları ve okuduğunu anlama becerileri arasındaki ilişki. Inönü Üniversitesi Eğitim Fakültesi Dergisi, 9 (16), 141-155.

Sarı, M., \& Cenkseven, F. (2008). İlköğretim Öğrencilerinde okul yaşam kalitesi ve benlik kavramı. 5. Uluslararası İnsan Bilimleri Dergisi. 7. 5., 2016 tarihinde www.insanbilimleri.com. adresinden alınd 1

Savignon, S. (1976). Communicative competence: Theory and classroom. 8 6, 2017 tarihinde http://files.eric. ed.gov/fulltext/ED135245.pdf adresinden alınd1

Schafer, R., \& Tait, J. (1986). A Guide for understanding attitudes and attitude change, Bulletin of the north central region extension sociology committee. North Central Region Extension Publication, 138, 1-11.

Smith, M. (1990). Longitudina iInvestigation of reading attitude development from childhood to adulthood. Journal of Educational Research, 83 (4), 215-219.

Stagner, R. (2014). Effects of ethnicity and gender on sixthgrade students' environmental knowledge and attitudes after participation in a year--long environmental education program. Dissertations and Theses.Portland State University. Center for Science Education. 7 4, 2016 tarihinde http://pdxscholar.library.pdx.edu/open_access_ etds/1539 adresinden alındı

Stange, T., \& Carter, E. (1995). Gifted middle grade readers: Attitudesand interests in the 90's. Paper Presented. $\mathrm{Pa}$ per Presented at the Annual Convention of the International Reading Association. CA, Anaheim: ED 391346

Türkçe Sözlük. (2005). Ankara: TDK.

Uluğ, M., Özden, M., \& Eryılmaz, A. (2011). The effects of teachers' attitudes on students' personality and. Procedia - Social and Behavioral Sciences, 30, 738-742.

Ulusoy, M. (2009). Boşluk tamamlama testinin okuma düzeyini ve okunabilirliği ölçmede kullanılması. Türk Ĕ̈itim Dergisi, 7 (1), 105-126.

Ünal, E. (2006). Illköğretim öğrencilerinin eleştirel okuma becerileri ile okuduğunu anlama ve okumaya yönelik tutumları arasındaki ilişki (Yayımlanmamış yüksek lisans tezi). Eskişehir: Osmangazi Üniversitesi.

Yıldırım, A., \& Şimşek, H. (2005). Sosyal bilimlerde nitel araştırma yöntemleri. Ankara: Seçkin Yayıncılık.

Yıldız, M. (2013). İlköğretim 3, 4 ve 5. sınıf öğrencilerinin okuma motivasyonlarının incelenmes. Eğitim ve Bilim, 38 (168), 260-271.

Yılmaz, F., \& Şekerci, H. (2016). Ana dil sorunsalı: Sınıf öğretmenlerinin deneyimlerine göre ilkokul öğrencilerinin yaşadıkları sorunlar. Eğitimde Nitel Araştırmalar Dergisi-ENAD, 4 (1). 